AEC

RESEARCH

\section{and \\ DEVELOPMENT}

\section{REPORT}

\title{
THERMAL STUDIES HASTELLOY X METALLIC INSULATION
}

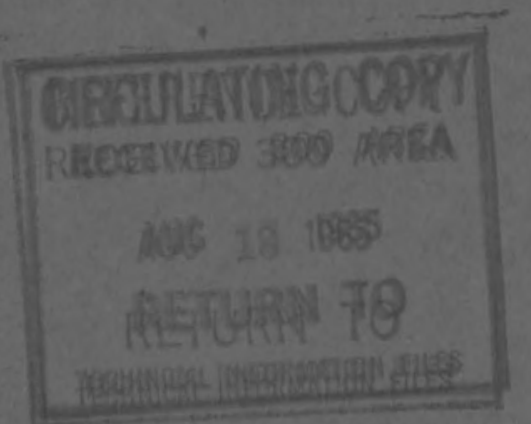

J. P. HICKERSON

AUGUST, 1965

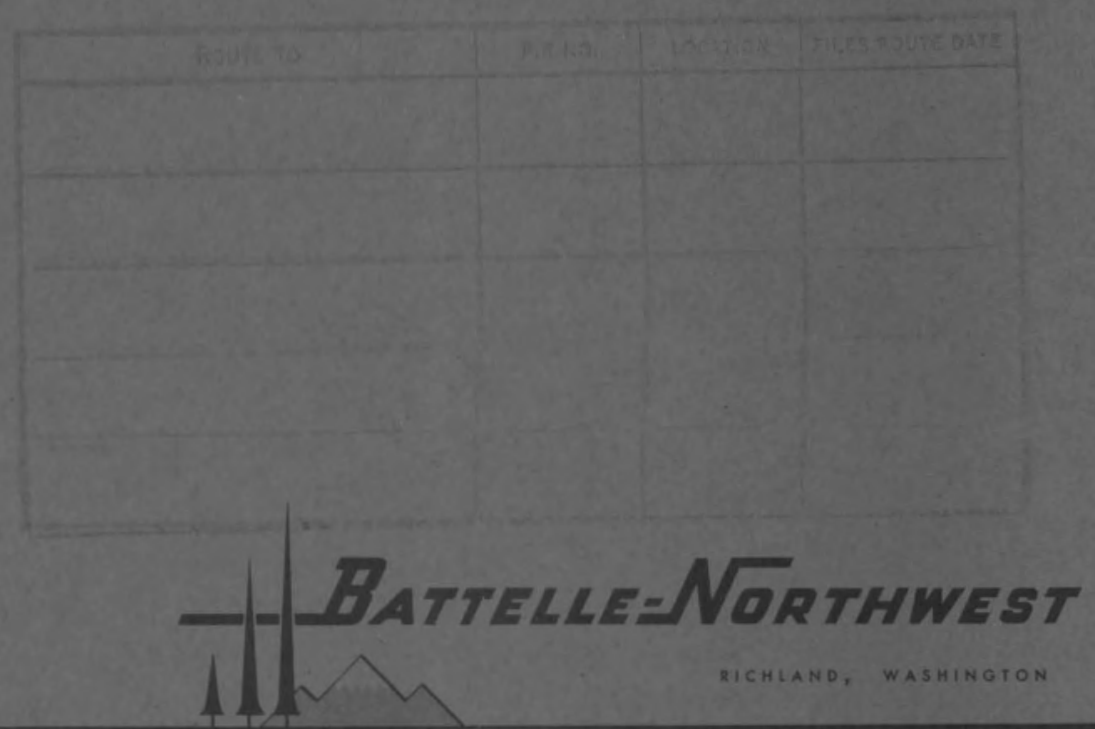

PACIFIC NORTHWEST LABORATORY operated by BATTELLE MEMORIAL INSTITUTE 


\section{LEGAL NOTICE}

This report was prepared as an account of Government sponsored work. Neither the United States, nor the Commission, nor any person acting on behalf of the Commission:

A. Makes any warranty or representation, expressed or implied, with respect to the accuracy, completeness, or usefulness of the information contained in this report, or that the use of any information, apparatus, method, or process disclosed in this report may not infringe privately owned rights; or

B. Assumes any liabilities with respect to the use of, or for damages resulting from the use of any information, apparatus, method, or process disclosed in this report.

As used in the above, "person acting on behalf of the Commission" includes any employee or contractor of the Commission, or employee of such contractor, to the extent that such employee or contractor of the Commission, or employee of such contractor prepares, disseminates, or provides access to, any information pursuant to his employment or contract with the Commission, or his employment with such contractor.

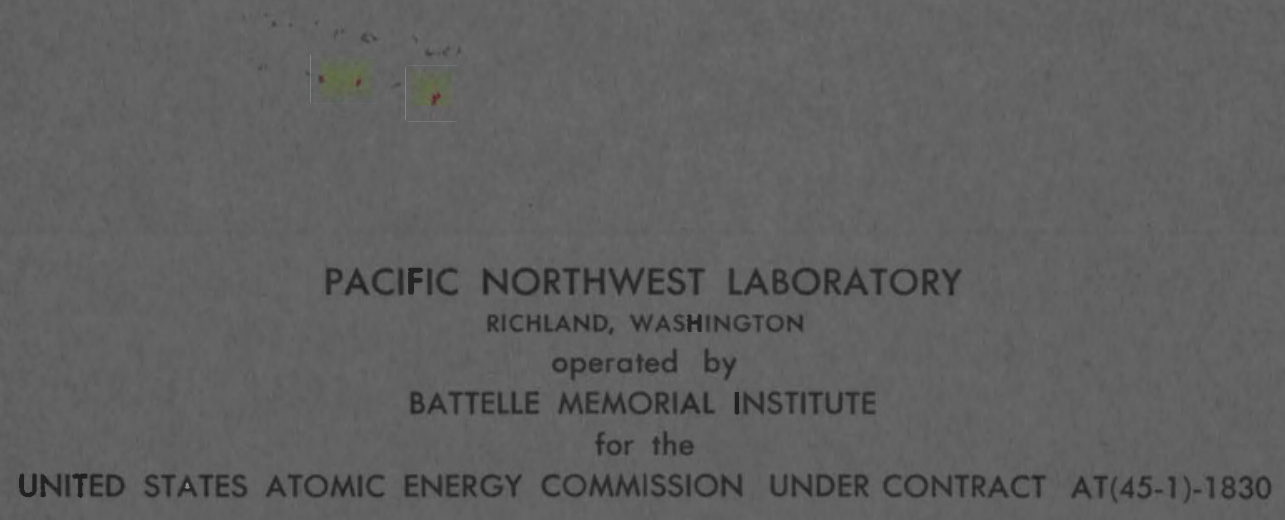

PRINTED BY/FOR THE U.S. ATOMIC ENERGY COMMISSION 
BNWL-102

UC-25, Metals, Ceramics, and Materials

THERMAL STUDIES

HASTELLOY X METALLIC INSULATION

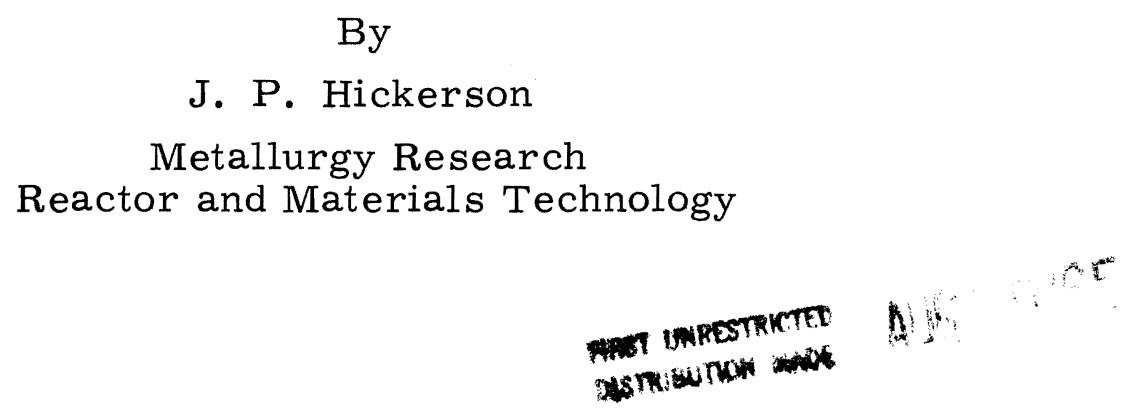

August, 1965 
Printed in USA. Price \$1.00. Available from the Clearinghouse for Federal Scientific and Technical Information, National Bureau of Standards, U.S. Department of Commerce, Springfield, Virginia 


\section{THERMAL STUDIES \\ HASTELLOY X METALLIC INSULATION}

\section{INTRODUCTION}

Hastelloy $\mathrm{X}$ wire wool has been considered by the Architect Engineer for exterior thermal insulation of some pipe sections of the ATR* gas loop. Heat transfer studies were made simulating gas loop operating conditions. This report describes the apparatus used and the resultant data.

The insulation (manufactured by a commercial supplier) is of interest because of its corrosion resistance, strength, and ability to withstand impact and abrasion. Also, it is not a source of chlorides. The insulation is produced in cylindrical sections and consists of Hastelloy $\mathrm{X}$ wire wool compressed and sintered to a given density and sinter bonded to a thin Inconel outer sheath.

\section{$\underline{\text { SUMMARY }}$}

In the search for insulation material for $\mathrm{ATR}^{*}$ gas loop piping, Hastelloy $\mathrm{X}$ wire wool has been considered by the Architect Engineer. To determine its suitability, thermal conductivity measurements were made under loop operating conditions.

\section{DESIGN AND CONSTRUCTION OF THE FURNACE}

Two 12-1/4 in. long half-cylindrical segments were received for study. The material was listed as:

Hastelloy $\mathrm{X}$ wire wool metallic insulation

$15 \%$ dense

5 -in. OD by 0.750 in. wall thickness

Bonded to 0.010-in. Inconel foil on the OD.

Because of the geometry of the pieces, thermal conductivity data could be most readily obtained by construction of a cylindrical, axially

* A $2000{ }^{\circ} \mathrm{F}$ helium gas loop through the core of the Advanced Test Reactor, Idaho Falls, Idaho. 
heated furnace designed to provide strictly radial heat flow. Figures 1 and 2 show the cross sections of the completed furnace. To maintain identity the two half cylinders are labeled Sections A and B.

Heat was provided by an axial Chromel A wound tube of Alundum 98 with Fiberfrax blanket scraps packed in its core. The metallic insulation was clamped around three segments (3.5 OD x 0.180-in. wall thickness) of 304 SS pipe by two 3/8-in. wide stainless straps, one at each end. The middle segment of pipe was 6-1/4 in. long with Fiberfrax washers placed at each end to prevent axial heat loss from the center segment and the interior air space.

Surrounding and clamped to the metallic insulation, was a fitted 1 -in. thick cylindrical section of K-23 insulating brick segments. The brick served to equalize heat transfer from the insulation outer wall and was also instrumented with thermocouples to serve as a heat meter. As an additional guard against axial heat flow, the ends of the composite cylinder were insulated with 5 in. of K-23 brick.

The complete furnace was placed inside a transite box with 1/2-in. wall thickness and ends covered with fiberglass blanket. This prevented air currents from removing heat unevenly from the furnace outer walls. INSTRUMENTATION

Throughout the furnace, calibrated chromel-alumel thermocouples were used as temperature sensors. Inconel sheathed thermocouples were used to detect the metallic insulation wall temperatures while the others were fiberglass insulated. The Inconel sheathed thermocouples were swaged to a point and tack welded longitudinally to the metallic insulation walls. The fiberglass sheathed thermocouples were inserted and cemented in longitudinal holes drilled in the $\mathrm{K}-23$ brick at selected radii from the furnace axis.

Power to the furnace was regulated by an a-c Variac power supply. Power consumption in the 6-1/4 in. central test section of the heater was measured directly by a calibrated wattmeter. 


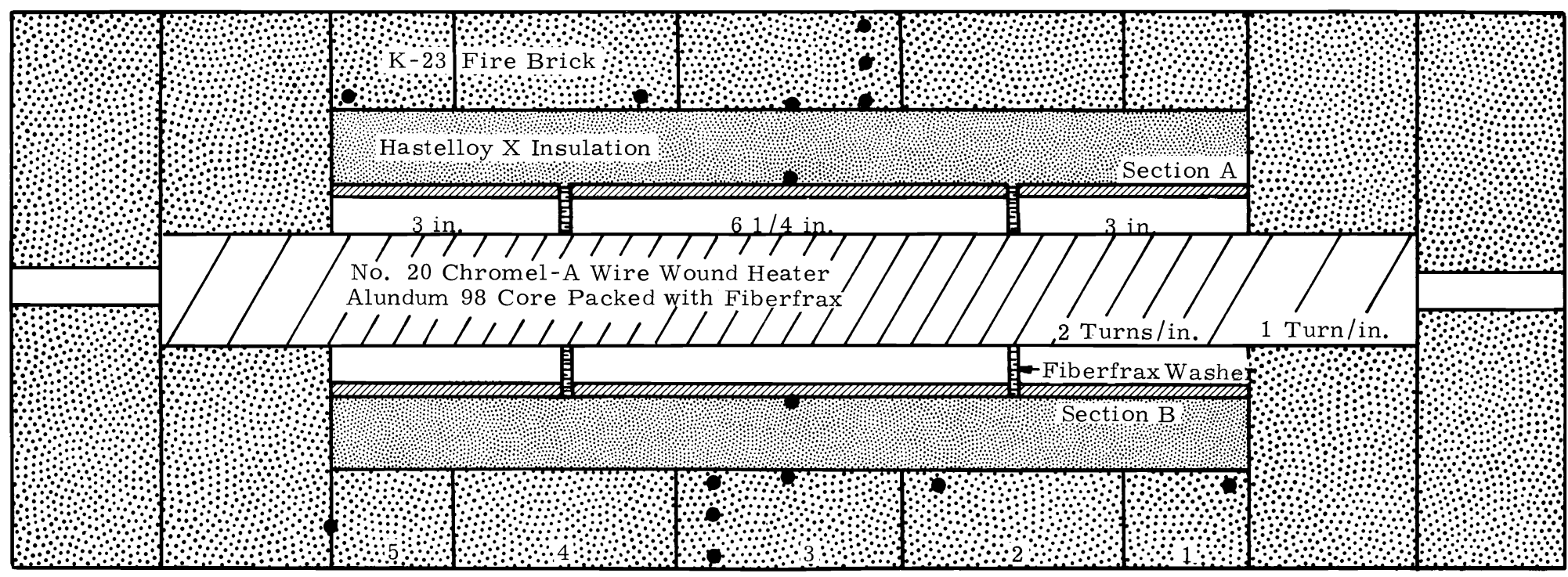

\section{FIGURE 1}

Schematic Diagram of the Furnace in Longitudinal Section Showing Geometry and Thermocouple Locations 


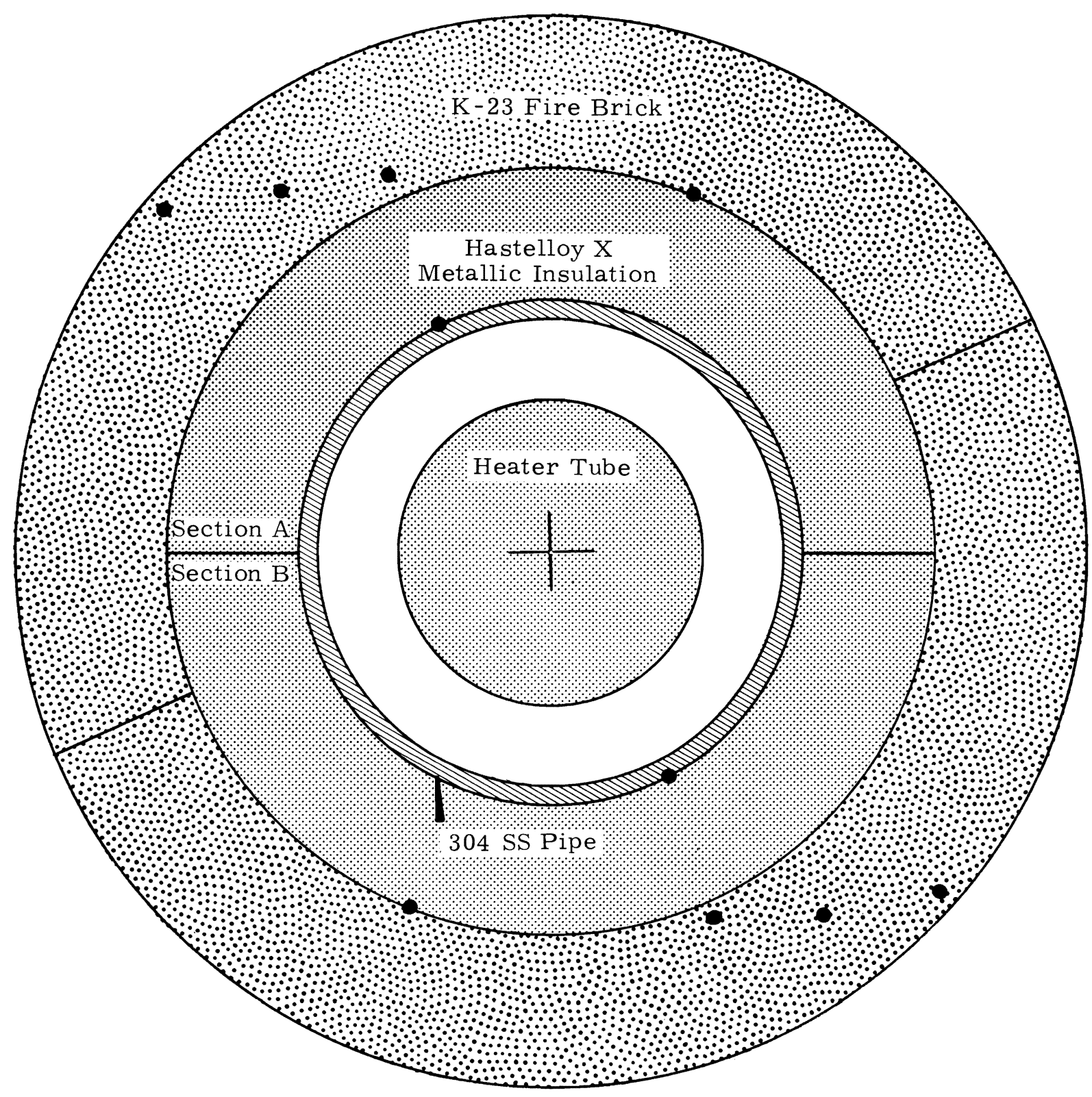

FIGURE 2

Schematic Diagram of the Furnace

in Transverse Section Showing Geometry 
Inner wall temperature of the felted metal insulation was monitored by a continuous chart recorder to indicate any fluctuations in power input. This record also helped to determine when the furnace had reached thermal equilibrium.

Temperature readings were made directly with a calibrated potentiometer.

OPERATING PROCEDURE

The procedure used to gain the data was as follows:

1. A desired furnace power input was selected and set, using the Variac power supply controls.

2. One metallic insulation inner-wall thermocouple was monitored by a continuous recorder to detect any major power fluctuation and indicate when temperature equilibrium was reached.

3. Twenty-four hours or more after the power level had been set, temperature and power consumption readings were taken. These readings were always taken in early morning hours or on weekends when fluctuations in furnace power input never exceeded $2 \%$ of total power.

Once started, the furnace was shut down only once (48 hr after initial startup). At that time, the metallic insulation was inspected and found to be essentially free of oxide after soaking at a mean temperature of $1000^{\circ} \mathrm{F}$. Thereafter, the furnace operated continuously until all data was gained. Data was taken first at the lower temperatures with power input being increased each day until the upper temperature limit of the heater was reached. Total operating time for the apparatus was 21 days.

\section{RESULTS}

The standard equation for cylindrical bodies and radial heat flow was used to make thermal conductivity calculations: $(1)$

1. W. D. Kingery. Property Measurements at High Temperatures, John Wiley and Sons, Inc., New York, p. 104. 


$$
\mathrm{K}=\frac{\mathrm{Q} \ln \frac{\mathrm{R}_{\mathrm{o}}}{\mathrm{R}_{\mathrm{i}}}}{\overline{2} \frac{\left.\mathrm{T}_{\mathrm{j}}-\mathrm{T}_{\mathrm{O}}\right)}{1(\mathrm{~T}}}
$$

where

$$
\begin{aligned}
\mathrm{K} & =\text { thermal conductivity } \\
\mathrm{Q} & =\text { the rate of heat transfer in a given section } \\
1 & =\text { length of a given section } \\
\mathrm{R}_{\mathrm{O}} & =\text { radius of the outer wall } \\
\mathrm{R}_{\mathrm{i}} & =\text { radius of the inner wall } \\
\mathrm{T}_{\mathrm{O}} & =\text { temperature of the outer wall } \\
\mathrm{T}_{\mathrm{i}} & =\text { temperature of the inner wall }
\end{aligned}
$$

The factor $Q$ was found by converting the power consumption of the test section directly to BTU/hr. All other coefficients were determined by direct measurement.

Table I shows the results of temperature measurements and the values for thermal conductivity. This data was then used to plot the standard curve of conductivity versus mean temperature shown in Figure 3.

While the insulation was listed by the manufacturer as having 0.750 -in. wall thickness, measurements showed wall thickness to be 0.80 -in. and 0.84-in. at thermocouple locations on Sections A and B, respectively.

\section{DISCUSSION}

Throughout its operation the furnace performed satisfactorily at all temperatures. Temperature distribution was uniform with Fahrenheit temperatures in the K-23 fire brick usually within $2 \%$ of each other. One exception existed at one end of the furnace where the temperature averaged 4 to $5 \%$ lower than the rest of the furnace. While this anomaly did affect the data, it was assumed to be insignificant.

The other data discrepancy resulted from dark oxide coatings on the wire wool above $1000^{\circ} \mathrm{F}$. This effect was apparent near the end of the test 
TABLE I

TEMPERATURE DATA POINTS

AND CORRESPONDING THERMAL CONDUCTIVITIES FOR 0.80 in. (A) AND 0.84 in. (B) WALL THICKNESSES

Thermal Conductivity

\begin{tabular}{|c|c|c|c|c|c|c|}
\hline \multirow[b]{2}{*}{ Section } & \multirow[b]{2}{*}{$\underline{\mathrm{T}}_{\text {mean }}$} & \multirow[b]{2}{*}{$\mathrm{T}_{\mathrm{i}}$} & \multirow[b]{2}{*}{$\mathrm{T}_{\mathrm{O}}$} & \multirow[b]{2}{*}{$\Delta \mathrm{T}$} & \\
\hline & & & & & Btu $/(\mathrm{hr})(\mathrm{ft})\left({ }^{\circ} \mathrm{F}\right)$ & Btu/in. $/(\mathrm{hr})\left(\mathrm{ft}^{2}\right)\left({ }^{\circ} \mathrm{F}\right)$ \\
\hline $\mathrm{A}$ & 703 & 873 & 534 & 339 & 0.119 & 1.42 \\
\hline $\mathrm{B}$ & 708 & 883 & 533 & 350 & 0.122 & 1.46 \\
\hline A & 875 & 1068 & 682 & 386 & 0.138 & 1.65 \\
\hline $\mathrm{B}$ & 876 & 1075 & 678 & 397 & 0.142 & 1.71 \\
\hline $\mathrm{A}$ & 932 & 1132 & 732 & 400 & 0.148 & 1.77 \\
\hline B & 935 & 1141 & 729 & 412 & 0.152 & 1.83 \\
\hline $\mathrm{A}$ & 1033 & 1248 & 818 & 430 & 0.165 & 1.97 \\
\hline B & 1036 & 1258 & 815 & 443 & 0.169 & 2.03 \\
\hline A & 1140 & 1358 & 921 & 437 & 0.187 & 2.24 \\
\hline B & 1144 & 1369 & 919 & 450 & 0.192 & 2.31 \\
\hline $\mathrm{A}$ & 1224 & 1445 & 1002 & 443 & 0.207 & 2.49 \\
\hline B & 1222 & 1450 & 993 & 457 & 0.213 & 2.56 \\
\hline A & 1264 & 1491 & 1038 & 453 & 0.219 & 2.63 \\
\hline B & 1266 & 1497 & 1035 & 462 & 0.228 & 2. 74 \\
\hline A & 1311 & 1536 & 1086 & 450 & 0.229 & 2.74 \\
\hline B & 1309 & 1538 & 1080 & 458 & 0.238 & 2.86 \\
\hline A & 1350 & 1576 & 1124 & 452 & 0.241 & 2.89 \\
\hline B & 1346 & 1576 & 1115 & 461 & 0.250 & 3.00 \\
\hline A & 1415 & 1640 & 1190 & 450 & 0.258 & 3.10 \\
\hline B & 1409 & 1642 & 1176 & 466 & 0.265 & 3.18 \\
\hline A & 1484 & 1712 & 1256 & 456 & 0.281 & 3.37 \\
\hline B & 1478 & 1714 & 1241 & 473 & 0.287 & 3.44 \\
\hline $\mathrm{A}$ & 1597 & 1825 & 1369 & 456 & 0.304 & 3.65 \\
\hline B & 1588 & 1825 & 1352 & 473 & 0.311 & 3.74 \\
\hline A & 1660 & 1896 & 1423 & 473 & 0.325 & 3.90 \\
\hline B & 1651 & 1896 & 1406 & 490 & 0.333 & 3.99 \\
\hline
\end{tabular}




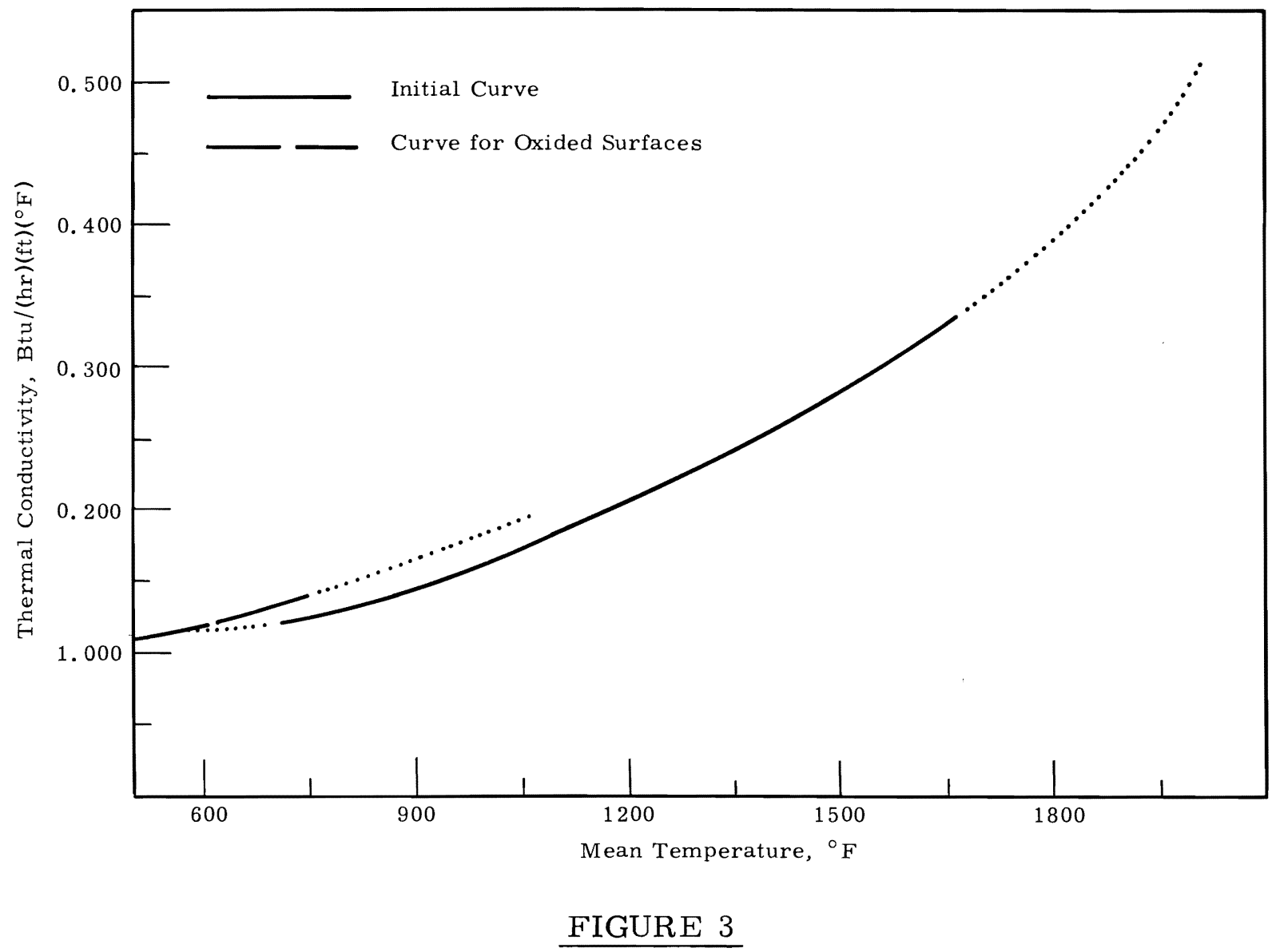

Thermal Conductivity Curve

for Hastelloy X Metallic Insulation

when the furnace power was lowered to gain three low temperature points on the curve. The slope for these three points was significantly steeper than that of the initial curve (Figure 3). However, since the oxide coating on the wire wool was certainly present when the upper portions of the initial curve were established, it was assumed that this secondary curve would intersect and gree with the initial curve at elevated temperatures. This indicates that the initial curve shown in Figure 3 actually gives low temperature conductivity values for bright wire surfaces and high temperature values for oxided wire surfaces.

Visual inspection of the metallic insulation was made after the furnace was dismantled. No adverse effects to the wire wool or its sintered bonds were found except where the wire wool had contacted the stainless 
pipe: a heavy scale had formed on the pipe and had become encrusted in the wool fibers. The fibers on this surface were corroded and highly embrittled. This condition extended inward to a depth of less than $0.050 \mathrm{in}$. where the wire was no longer in contact with the scale from the stainless pipe. Figure 4 shows the general appearance of the insulation after the furnace was dismantled.

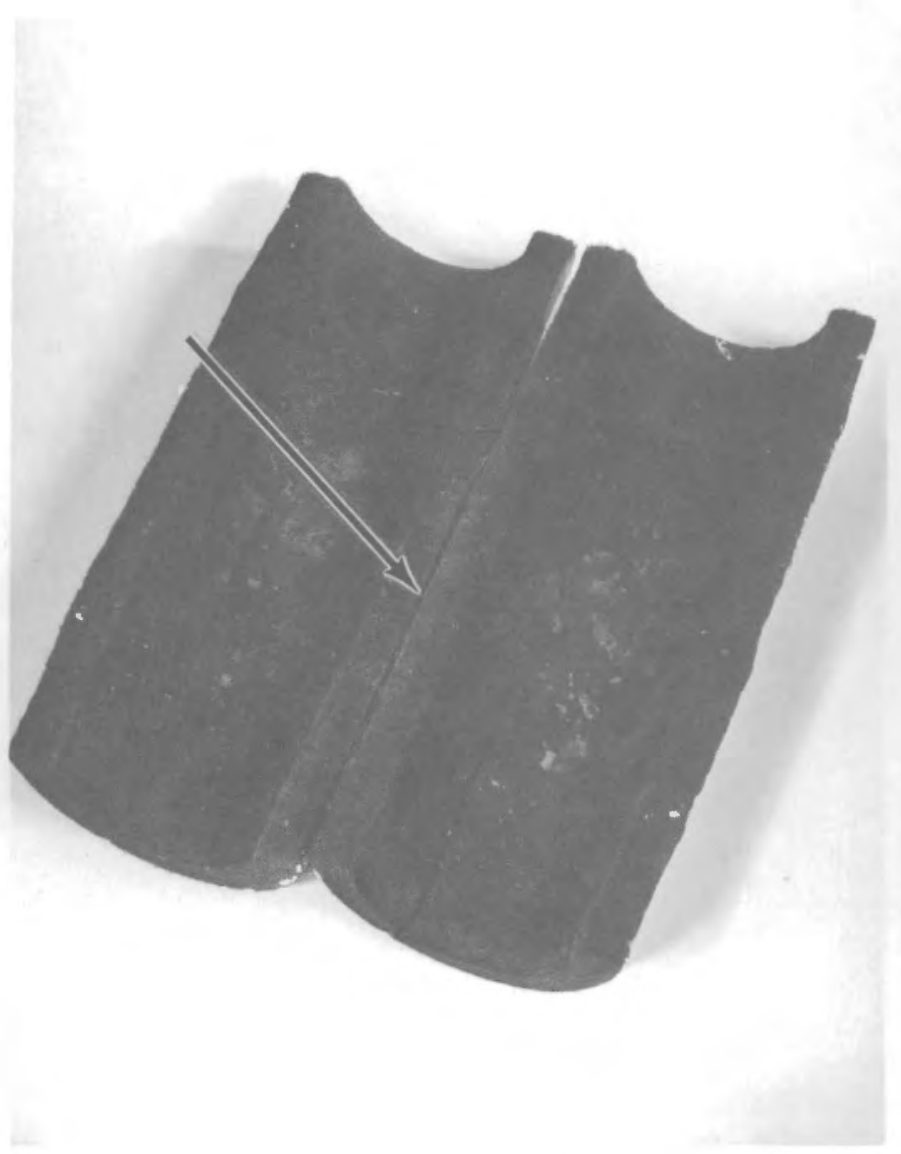

A. Inside Surface of the Two 12-1/4 in. Long Sections

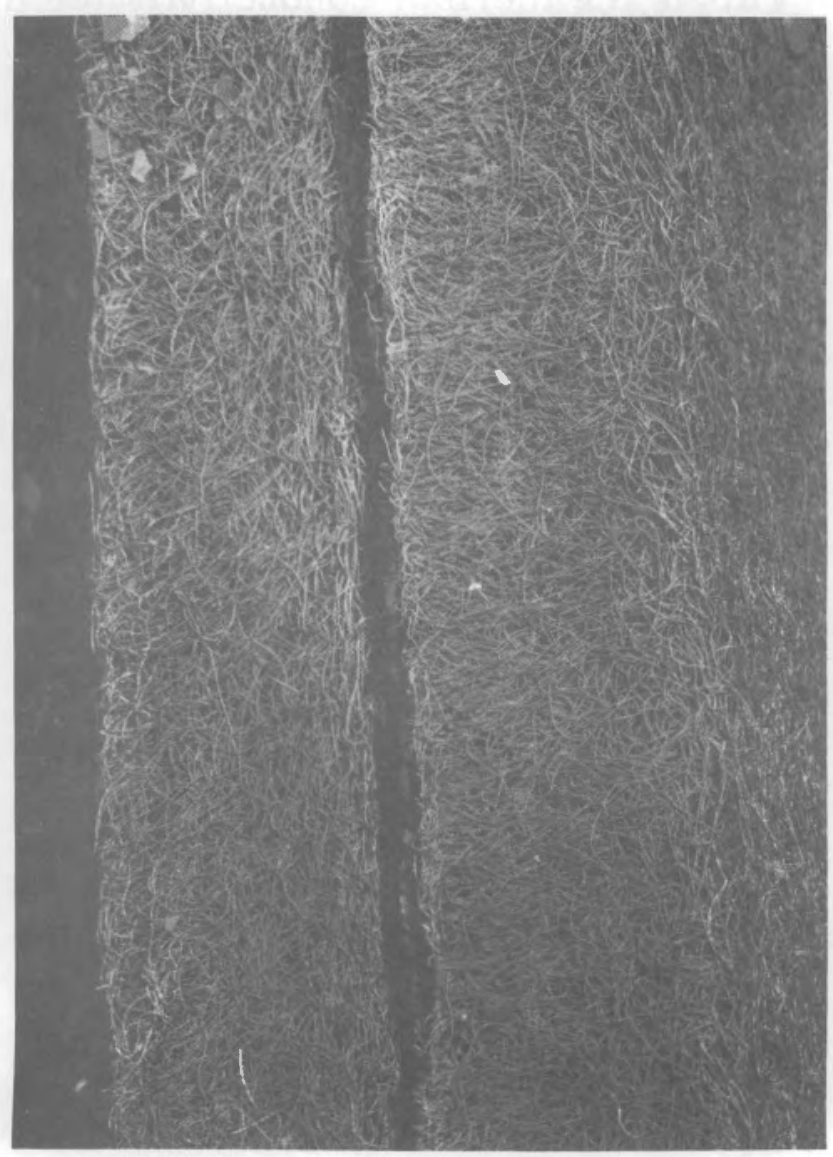

B. Close-Up of Wall Section Indicated in $\mathrm{A}$. $\sim 1.3 \mathrm{X}$

FIGURE 4

Appearance of Hastelloy X Metallic Insulation After Removal from the Furnace 
The felted wire was manufactured to be $15 \%$ dense for a 0.750 -in wall thickness, but the insulation was somewhat less dense since actual wall thickness was about $0.80 \mathrm{in}$. The difference is small though, (about $1 / 20$ less than the manufactured density) and these results should apply well to $15 \%$ dense material.

The curve obtained appears to be representative and should serve well for most purposes. It should be noted, however, that low temperature regions of the curve give values for bright wire wool surfaces. The oxide raises the thermal conductivity for the insulation. 


\section{ONSITE DISTRIBUTION}

Copy Number

Pacific Northwest Laboratory

$\begin{array}{ll}1 & \\ 2 & \\ 3 & \\ 4 & \\ 5 & -7 \\ 8 & -10 \\ 11 & \\ 12 & -15 \\ 16 & -20 \\ 21 & \\ 22 & -23\end{array}$

J. J. Cadwell

D. R. deHalas

R. L. Dillon

H. Harty

J. P. Hickerson

D. C. Kaulitz

J. E. Minor

R. G. Wheeler

Technical Information Files 300 Area Technical Publications 700 Area Technical Publications

Richland Operations Office

24

25

R. K. Sharp

Technical Information Library

OFFSITE DISTRIBUTION (Special)

No. of Copies

1

Battelle Memorial Institute 5455 Wilshire Blvd

Los Angeles, California

Dept. of Materials Engineering

Attn: E. W. Cawthorn

1

Battelle Memorial Institute Columbus, Ohio

Dept. of Materials Engineering

Attn: R. J. Runck 